\title{
PENGARUH MOTIVASI KERJA DAN KOMPENSASI TERHADAP KINERJA KARYAWAN PADA PT LARIS INDO SUKSES GEMILANG TANGERANG SELATAN
}

\author{
Dewi Sartika \\ Riski Dwi Nugroho \\ Inama Elliska
}

\begin{abstract}
Staf Pengajar Dan Mahasiswa Fakultas Ekonomi Universitas Pamulang email :dosen02208@unpam.ac.id,dosen02296@unpam.ac.id
\end{abstract}

\begin{abstract}
ABSTRAK
Penelitian ini bertujuan untuk mengetahui pengaruh motivasi kerja dan kompensasi terhadap kinerja karyawan pada PT. Laris Indo Sukses Gemilang Tangerang Selatan. Penelitian studi kasus dengan metode kuantitatif dengan sampel penelitian 40 responden yang merupakan karyawan di PT. Laris Indo Sukses Gemilang Tangerang Selatan. Untuk melihat pengaruh variabel bebas pada variabel terikat, pengolahan data menggunakan software SPSS. Hasil dari penelitian membuktikan motivasi kerja dan kompensasi berpengaruh penting pada kinerja karyawan di PT. Laris Indo Sukses Gemilang Tangerang Selatan.
\end{abstract}

\section{Kata Kunci : Motivasi Kerja, Kompensasi, Kinerja Karyawan}

\begin{abstract}
This study aims to see work motivation and compensation for employee performance at PT. Laris Indo Sukses Gemilang South Tangerang. Research case study with quantitative method with research sample 40 respondents who are employees at PT. Laris Indo Sukses Gemilang South Tangerang. To see the effect of independent variables on data processing variables using SPSS software. The results of work motivation research and an important effect on employee performance at PT. Laris Indo Sukses Gemilang South Tangerang. Keywords: Work Motivation, Compensation, Employee Performance
\end{abstract}

\section{Keyword: Product Quality, Brand Image, Customer Loyalty}

\section{PENDAHULUAN}

\subsection{Latar Belakang}

Di era globalisasi ini, dunia bisnis menunjukan perkembangan yang sangat pesat, diikuti dengan munculnya berbagai perusahaan-perusahaan baru yang bergerak pada berbagai bidang. Perusahaan tersebut selalu berusaha untuk mendapatkan posisi maupun kondisi yang menguntungkan. Kondisi seperti ini akan menimbulkan suatu persaingan yang sangat ketat antar perusahaan yang ada.
Persaingan juga semakin ketat dengan adanya perkembangan informasi serta semakin meningkatnya teknologi sehingga mengakibatkan adanya persaingan secara global dan menyeluruh.

Sumber daya manusia merupakan faktor penting dalam suatu organisasi atau perusahaan agar aktivitas manajemen berjalan dengan baik, perusahaan harus memiliki karyawan yang berpengetahuan dan berketerampilan tinggi serta usaha untuk mengelola perusahaan seoptimal 
mungkin sehingga kinerja karyawan meningkat. Perubahan dan karyawan merupakan dua hal yang saling membutuhkan. Jika karyawan berhasil membawa kemajuan bagi perusahaan, keuntungan yang diperoleh akan dipetik oleh kedua belah pihak. Bagi karyawan keberhasilan merupakan aktualisasi potensi diri sekaligus peluang untuk memenuhi kebutuhan hidupnya. Sedangkan bagi perusahaan, keberhasilan merupakan sarana menuju pertumbuhan dan perkembangan perusahaan.

Setiap perusahaan selalu menginginkan produktivitas dari setiap karyawannya meningkat. Untuk mencapai hal tersebut, perusahaan harus memberikan motivasi yang baik kepada seluruh karyawannya agar dapat mencapai prestasi kerja dan meningkatkan produktivitas. Dengan ditambah pengalaman kerja yang dimiliki oleh para karyawannya, akan memberikan suatu hubungan yang besar dalam upaya mencapai tingkat produktivitas.

Dalam melakukan usaha meningkatkan produktivitas kerja ini, PT. Laris Indo Sukses Gemilang telah menetapkan beberapa upaya yang bertujuan untuk memotivasi kerja para karyawannya. Adapun upaya tersebut dengan memberikan beberapa fasilitasfasilitas kerja yang sangat menunjang dalam meningkatkan produktivitas kepada seluruh karyawanya.

Fasilitas-fasilitas tersebut meliputi pakaian kerja, jaminan makan, rekreasi, tempat ibadah, ruang olahraga, tunjangan hari raya, ruang pengobatan, gaji, bonus, upah lembur dan sebagainya. Semua itu diberikan oleh perusahaan, agar seluruh karyawan yang bekerja di dalamnya benarbenar terjamin sekaligus dapat menciptakan suatu motivasi yang baik guna mencapai tingkat produktivitas.

Tingkat pendidikan dan pengalaman kerjapun diutamakan. Khususnya untuk bagian Admin, Kasir, dan SPG (Sales Promotion Girls) minimal berbatas pendidikan SLTA. Sedangkan bagian yang mempacking produk untuk dijual dan yang mengirim barang minimal berpendidikan SMP. Namun dalam proses perekrutan karyawan, perusahaan lebih mengutamakan calon karyawan yang sudah mempunyai pengalaman kerja dari perusahaan yang sejenis. Ini semua diharapkan bisa menciptakan semangat kerja sekaligus prestasi kerja yang tinggi dalam menggapai perwujudan tingkat produktivitas yang baik, seperti yang diharapkan perusahaan.

Kemampuan individu sebagai tenaga kerja dikatakan sebagai sumber utama dalam melakukan aktivitas operasi.. keoptimalan hasil kerja agar sesuai dengan target yang sudah direncanakan sebelumnya didapat jika kualitas tenaga kerja berperan aktif, sejatinya karena mereka mempunyai bakat, tenaga dan kreativitas yang sangat dan dibutuhkan oleh perusahaan untuk mencapai tujuannya.

Disisi lain bahwa tenaga kerja tersebut memiliki kewajiban dalam memnuhi kebutuhan hidupnya. Inilah yang menjadi dasar bahwa dengan memenuhi kebutuhan inilah yang dapat memotivasi seseorang untuk melakukan sesuatu termasuk untuk melakukan pekerjaan atau bekerja, hal lainnya adalah adanya kompensasi, karena besar kecilnya kompensasi merupakan ukuran terhadap skill yang dimiliki karyawan dan sebagai reward yang diberikan perusahaan. Dengan kata lain bahwa jika kompensasi terpenuhi secara adil, maka akan mendorong karyawan untuk semaksimal mungkin menyelesaikan pekerjaannya dan lebih bertanggung jawab atas apa yang dikerjakannya.

Tujuan kompensasi dilakukan perusahaan antara lain untuk menghargai prestasi karyawan, menjamin keadilan diantara karyawan, mempertahankan pegawai, memperoleh karyawan yang 
lebih bermutu, dan sistem kompensasi seharusnya bisa memberikan dapat memotivasi para karyawan. Oleh karena itu, Motivasi adalah suatu faktor yang mendorong seseorang untuk melakukan suatu aktivitas tertentu.

Maka dapat dirinci kembali bahwa faktor pendukung seseorang untuk melaksanakan aktivitas kerjanya adalah karena adanya kebutuhan yang harus dipenuhinya, dimana kinerja perusahaan dapat dinilai dari motivasi kerja karyawannya.

\subsection{Perumusan Masalah}

Perumusan masalah penelitian sebagai berikut:

1. Adakah pengaruh motivasi kerja terhadap kinerja karyawan?

2. Adakah kompensasi terhadap perio karyawan?"

\subsection{Tujuan Penelitian}

Tujuan penelitian ini yaitu:

1. Mengetahui pengaruh motivasi kerja terhadap kinerja karyawan.

2. Mengetahui pengaruh kompensasi terhadap kinerja karyawan.

\section{TINJAUAN PUSTAKA}

\subsection{Motivasi Kerja}

Menurut Muchdarsyah (2012:205) berpendapat jika motivasi kerja yaitu sebuah attitude yang memberikan energy dan sebuah encouragement nilai dalam mengarahkan atau mengubah perilaku untuk mencapai kepbutuhan yang dapat memberikan kepuasan dan mencapai keseimbangan.

Menurut Rivai (2012:455) yaitu urutan sikap dan value yang dapat merubah seseorang dalam mencapai suatu hal yang lebih spesifik menuju tujuan yang telah ditetapkan orang tersebut. attitude dan value tersebut adalah sesuatu pakem yang mampu mendorong seseorang untuk melakukan sesuatu dalam mencapai tujuan.
Dasar dari statement ahli tersebut dapat disimpulkan bahwa motivasi digambarkan layaknya dorongan dan penggerak yang dapat menciptakan kegairahan dan membangkitkan semangat kerja seseorang untuk melakukan suatu tindakan atau perbuatan agar mau bekerjasama untuk mencapai tujuan yang telah ditetapkan sebelumnya.

\subsection{Kompensasi}

Menurut Dessler (2012:46), kompensasi karyawan adalah semua bentuk pembayaran atau hadiah yang diberikan kepada karyawan dan muncul dari pekerjaan mereka.

Menurut Sinamora (2012:441), Kompensasi (Compensation) meliputi imbalan finansial dan jasa serta tunjangan yang diterima oleh para karyawan oleh para karyawan sebagai bagian dari hubungan kepegawaian. Kompensasi merupakan apa yang diterima oelh para karyawan sebagai ganti kontribusi mereka kepada organisasi.

Menurut Hasibuan (2012:118), kompensasi adalah semua pendapatan yang berbentuk uang atau barang langsung mampu tidak langsung yang diterima karyawan sebagai imbalan jasa yang telah diberikan kepada perusahaan.

Dari uraian yang telah dijelaskan ditarik kesimpulan terkait dengan kompenssasi yaitu imbalan yang mencerminkan ukuran nilai karya diantara para karyawan dalam melakukan tugas dalam melaksanakan tugas dan pekerjaan.

\section{Jenis- jenis Kompensasi}

Pada dasarnya kompensasi dapat dikelompokkan kedalam dua kelompok, yaitu : 
a. Kompensasi Finansial

Menurut Desler (2012:46), kompensasi finansial yang diberikan secara langsung kepada karyawan dibagi menjadi dua diantaranya yaitu:

1) Kompensasi Langsung (Direct Compesation) yang terdiri dari bayaran pokok/gaji, bayaran prestasi, bayaran intensif dan bayaran tertanggung.

2) Kompensasi tidak langsung (Indirect Compesation) yang terdiri dari program proteksi seperti asuransi keseluruhan, bayaran diluar jam kerja seperti cuti hamil,dan fasilitas lainnya seperti kendaraan dan ruang kantor.

\section{b. Kompensasi Non Finansial}

1) Pekerjaan, yaitu tugas- tugas yang menarik, tantangan, tanggung jawab, pengakuan, dan rasa pencapaian.

2) Lingkungan kerja, yaitu kebijakan yang sehat, supervise yang kompeten, kerabat kerja yang menyenangkan, dan lingkungan kerja yang nyaman.

\subsection{Kinerja Karyawan}

Menurut Hasibuan (2012:34) kinerja adalah suatu hasil kerja yang dicapai seseorang dalam melaksanakan tugas-tugas yang dibebankan kepadanya yang berdasar kepada waktu, pengalaman, kesungguhan, dan kecakapan.

Menurut Mangkuprawira dan Hubeis (2012:153) kinerja yaitu hasil proses pekerjaan tertentu secara terencana pada waktu dan tempat dari karyawan serta organisasi bersangkutan.

Mangkunegara (2012:67) kinerja karyawan adalah hasil kerja secara kualitas dan kuantitas yang dicapai oleh seorang karyawan dalam melaksanakan tugasnya sesuai dengan tanggung jawab yang diberikan kepadanya.

Dari beberapa pengertian di atas, maka dapat disimpulakan kinerja karyawan adalah hasil kerja secara kualitas dan kuantitas yang dicapai oleh seorang karyawan dalam melaksanakan tugasnya sesuai dengan tanggung jawab yang diberikan kepadanya.

Tujuan spesifik ditetapkan manajemen kinerja menurut Armstrong (2012:44) adalah :

a. Mencapai peningkatan yang dapat diraih dalam kinerja organisasi

b. Bertindak sebagai pendorong perubahan dalam mengembangkan suatu budaya yang berorientasi kepada kinerja.

c. Meningkatkan motivasi dan komitmen karyawan

d. Memberikan kesempatan individu untuk mengungkapkan aspirasi dan perhatian mereka tentang pekerjaan mereka

e. Menunjukan pada setiap orang bahwa organisasi menilai mereka sebagai induvidu

f. Membantu mempertahankan orang - orang dalam kualitas yang tinggi.

\subsection{Kerangka Pemikiran}

Berdasarkan uraian tersebut diiatas terkait pembinaan organisasi dan karyawan PT. Laris Indo Sukses Gemilang bahwa kinerja karyawan dapat ditingkatkan apabila motivasi kerja dapat dioptimalkan dengan baik sehingga mampu meningkatkan kinerja karyawan sebagai upaya mengwujudkan tujuan organisasi dan perusahaan.

Menurut Maslow dalam Amirullah (2016) menjelaskan bahwa motivasi kerja ini memandang manusia mempunyai kebutuhan yang bertingkat- 
tingkat dari paling sederhana hinga paling tinggi berdasarkan kadar kepentingannya. Karyawan dipengaruhi oleh kebutuhan kebutuhan fisik akan penghargaan diri, dan kebutuhan aktualisasi diri. Kemudian dari faktor kebutuhan tersebut ditelaah dan ditelusuri menjadi indikator-indikator untuk mengetahui motivasi kerja karyawan, yaitu a) Kebutuhan Fisik, b) Kebutuhan Akan Rasa Aman, c) Kebutuhan Sosial, d) Penghargaan, e) Aktualisasi Diri.

Motivasi merupakan dorongan seseorang untuk melakukan sesuatu perbuatan. Motivasi bisa bersifat kasat mata maupun pula tidak terlihat secara fisik namun dapat dirasakan suasananya secara emosional dan dapat mempengaruhi prilaku karyawan serta kinerja karyawan.

Menurut Moeheriono (2016:152) kinerja merupakan gambaran tingkat pelaksanaan suatu program kegiatan atau kebijakan dalam mewujudkan tujuan, visi, dan misi organisasi yang dituangkan melalui perencanaan strategis suatu organisasi. Indikator untuk mengukur kinerja karyawan secara individu ada enam indikator, yaitu a) Efektif, b) Efisien, c) Kualitas, d) Ketepatan Waktu, e) Keselamatan.

Kompensasi merupakan semua pendapatan yang berbentuk uang, barang langsung atau tidak langsung yang diterima karyawan sebagai imbalan atas jasa yang diberikan kepada perusahaan.

Berikut kerangka pemikiran penelitian :

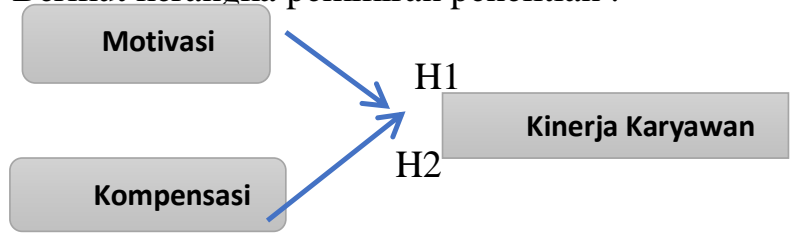

\section{METODOLOGI PENELITIAN}

\subsection{Rancangan Penelitian}

Penelitian ini mengacu pada penelitian yang telah dilakukan oleh Hesti Maheswari (2015) yang menganalisis pengaruh kompensasi dan motivasi terhadap kinerja karyawan PT Bank Ekonomi Raharja Tbk Area Jakarta 5. Metode yang digunakan adalah data kuantitatif dengan kuesioner terhadap konsumen di PT. Laris Indo Sukses Gemilang Tangerang Selatan.

\subsection{Variabel dan pengukuran}

\subsubsection{Variabel}

Variabel penelitian terdiri dari:

1. Variabel Bebas (Independent Variable)

Variabel bebas yang mempengaruhi variabel terikat yaitu motivasi kerja dan kompensasi.

\section{A. Motivasi Kerja}

Motivasi menurut Maslow dalam Hasibuan (2017:153) manusia mempunyai sejumlah kebutuhan yang diklasifikasinya pada lima tingkatan atau hirarki (hierarchy of needs) sebagai berikut:

1) Kebutuhan Fisiologikal yaitu kebutuhan yang bersifat materi atau kadang kala disebut sebagai kebutuhan primer.

2) Kebutuhan akan keamanan yang sering kali dinamakan orang kebutuhan akan keamanan (security needs).

3) Kebutuhan sosial yang sering kali disebut social needs.

4) Kebutuhan akan penghargaan.

5) Kebutuhan akan aktualisasi diri.

B. Kompensasi

Berbagai faktor yang mempengaruhi tingkat kompensasi yang dikemukakan Hasibuan (2012:128) antara lain:

1) Penawaran dan permintaan tenaga kerja

2) Kemampuan untuk membayar 
3) Organisasi buruh/organisasi karyawan

2. Variabel terikat Variable)

(Dependent

Variabel terikat yang dipengaruhi oleh variabel bebas yaitu kinerja karyawan

\section{A. Kinerja Karyawan}

Aspek-aspek yang dibahas dalam penilaian kinerja, antara lain adalah sebagai berikut :

1) Validity adalah keabsahan standar tersebut sesuai dengan jenis pekerjaan yang dinilai.

2) Agreement adalah persetujuan, yaitu standar penilaian tersebut disetujui dan diterima oleh semua karyawan yang akan mendapat penilaian.

3) Realisme adalah standar penilaian tersebut bersifat realistis, dapat dicapai oleh para karyawan dan sesuai dengan kemampuan karyawan.

4) Objectivity adalah standar penilaian bersifat objektif.

\subsection{Populasi dan Sampel Penelitian}

Populasi merupakan keseluruhan subyek penelitian. Populasi penelitian ini adalah karyawan di PT. Laris Indo Sukses Gemilang Tangerang Selatan. Dalam penelitian ini penulis menggunakan sampel jenuh karena keterbatasan populasi yang akan dijadikan sampel dalam penelitian. Menurut Sugiyono (2017:85) sampling jenuh adalah teknik penentuan sampel bila semua anggota populasi digunakan sebagai sampel.

Pada pembahasan populasi dan sampel diatas penulis menyimpulkan, untuk populasi atau jumlah keseluruhan PT. Laris Indo Sukses Gemilang sebanyak 40 orang. Pemakaian atau pemilihan sampel yang digunakan adalah sampel jenuh, adalah teknik penentuan sampel bila semua anggota populasi digunakan sebagai sampel.

\section{Metode Pengumpulan Data}

Data diambil sesuai tujuan penelitian, kemudian diolah untuk mendapatkan kesimpulan. Sumber berasal dari:

1. Penelitian Lapangan (Data Primer)

Untuk mendapatkan data, peneliti mendatangi tempat yang menjadi obyek. Peneliti menggunakan kuesioner sebagai media pengumpulan sampel.

2. Penelitian Kepustakaan (Data Sekunder)

Peneliti meggunakan buku dan jurnal yang secara teoritis meneliti variabel ketiga variabel tersebut.

\subsection{Metode Analisis Data}

Metode analisis adalah kuantitatif yaitu angka-angka yang dapat dihitung dan diukur. Pengolahan data pada metode ini melalui beberapa tahap.

\subsubsection{Uji Validitas}

Untuk mendapatkan hubungan tiap indikator terhadap skor totalnya digunakan teknik pearson correlation, sehingga diketahui validitasnya. Dasar pengambilan keputusan:

- Nilai pearson <0,05: valid.

- Nilai pearson >0,05: tidak valid.

\subsubsection{Uji Reabilitas}

Untuk menentukan konsistensi, akurasi, dan predictable variabel yang digunakan dengan melihat koefisien Cronbach's Alpha. Dasar pengambilan keputusan:

- Nilai koefisien >0,6: reliable.

- Nilai koefisien <0,6: tidak reliable.

\subsubsection{Analisa Regresi Berganda}

Untuk mengetahui pengaruh positif motivasi kerja dan kompensasi pada kinerja karyawan.

Bentuk persamaan sebagai berikut: $\mathrm{Y}=\alpha+\left(\beta_{\mathrm{MK}} \mathrm{X}_{\mathrm{MK}}\right)+\left(\beta_{\mathrm{K}} \mathrm{X}_{\mathrm{K}}\right)$ 
Keterangan:

$$
\begin{array}{ll}
\mathrm{Y} & =\text { Kinerja karyawan } \\
\alpha & =\text { Konstanta } \\
\beta_{\mathrm{MK}}, \beta_{\mathrm{K}} & =\text { Koefisien estimasi } \\
\mathrm{X}_{\mathrm{MK}} & =\text { Motivasi kerja } \\
\mathrm{X}_{\mathrm{K}} & =\text { Kompensasi }
\end{array}
$$

\subsubsection{Uji Hipotesis}

1. Uji t

Untuk melihat apakah tiap variabel bebas mempengaruhi variabel terikat secara terpisah. Hipotesis sebagai berikut:

- Signifikasi <0,05: terdapat pengaruh signifikan variabel bebas pada variabel terikat.

- Signifikasi >0,05: tidak terdapat pengaruh signifikan variabel bebas pada variabel terikat.

2. Uji Goodness of Fit (Uji F dan $\mathbf{R}^{2}$ )

Untuk mengukur kesesuaian sampel antara harapan dengan aktual digunakan:

A. Uji F (Uji Simultan)

Untuk melihat apakah semua variabel bebas memiliki pengaruh pada variabel terikat secara simultan. Hipotesis sebagai berikut:

- Signifikansi <0,05: terdapat pengaruh signifikan variabel bebas pada variabel terikat secara simultan.

- Signifikansi >0,05: tidak terdapat pengaruh signifikan variabel bebas pada variabel terikat secara simultan.

B. Koefisien Determinasi $\left(\mathrm{R}^{2}\right)$

Untuk menaksir kesanggupan pola dalam menjelaskan variasi variabel terikat. Nilai $R^{2}$ adalah $0<\mathrm{R}^{2}<1$. adjusted $R$ square apabila mendapat tambahan variabel bebas nilainya dapat berubah. Oleh karena itu, untuk mendapatkan model regresi terbaik digunakan nilai adjusted $R$ square (Ghozali, 2006).

\section{ANALISA DAN PEMBAHASAN \\ 4.1 Profil Responden}

\begin{tabular}{|c|c|c|c|}
\hline No & \begin{tabular}{|l|} 
Profil \\
Responden \\
\end{tabular} & Jumlah & $\begin{array}{l}\text { Presentase } \\
(\%)\end{array}$ \\
\hline 1 & $\begin{array}{l}\text { Jenis Kelamin } \\
\text { a. Pria } \\
\text { b. Wanita }\end{array}$ & $\begin{array}{l}15 \text { orang } \\
25 \text { orang }\end{array}$ & $\begin{array}{l}37,5 \% \\
62,5 \%\end{array}$ \\
\hline 2 & \begin{tabular}{ll}
\multicolumn{2}{c}{ Usia Karyawan } \\
a. $\quad<20$ \\
b. $21-30$ \\
c. $1-40$ \\
d. $\quad>40$
\end{tabular} & $\begin{array}{l}3 \text { orang } \\
23 \text { orang } \\
12 \text { orang } \\
2 \text { orang }\end{array}$ & $\begin{array}{l}8 \% \\
57 \% \\
30 \% \\
5 \%\end{array}$ \\
\hline 3 & $\begin{array}{l}\text { Pendidikan } \\
\text { Terakhir } \\
\text { a. SLTA } \\
\text { b. Diploma } \\
\text { c. Sarjana }\end{array}$ & $\begin{array}{l}7 \text { orang } \\
10 \text { orang } \\
23 \text { orang }\end{array}$ & $\begin{array}{l}18 \% \\
25 \% \\
57 \%\end{array}$ \\
\hline 4 & $\begin{array}{l}\text { Lama Bekerja } \\
\text { a. } \quad<1 \text { tahun } \\
\text { b. } \quad 1-5 \text { tahun } \\
\text { c. } \quad>5 \text { tahun }\end{array}$ & $\begin{array}{l}20 \text { orang } \\
10 \text { orang } \\
10 \text { orang }\end{array}$ & $\begin{array}{l}50 \% \\
25 \% \\
25 \% \\
\end{array}$ \\
\hline
\end{tabular}
berikut:

Hasil ditampilkan pada tabel sebagai

Tabel 4.1

Profil Responden

Sumber: PT. Laris Indo Sukses Gemilang Tangerang Selatan, 2019

Hasil pengumpulan data profil responden berdasarkan gender, umur karyawan, pendidikan terakhir dan masa bekerja di PT. Laris Indo Sukses Gemilang Tangerang Selatan, dapat disimpulkan bahwa karyawan PT. Laris Indo Sukses Gemilang Tangerang Selatan didominasi oleh wanita, mayoritas responden karyawan PT. Laris Indo Sukses Gemilang Tangerang Selatan dilihat dari usia adalah antara 21-30 tahun, pendidikan terakhir karyawan PT. Laris Indo Sukses Gemilang Tangerang Selatan didominasi oleh Sarjana Strata 1 (S1). Lama bekerja di PT. Laris Indo Sukses Gemilang Tangerang Selatan adalah kurang dari setahun.

\subsection{Analisa Data}

\subsubsection{Hasil Uji Validitas}


Hasil uji validitas variabel ditampilkan pada tabel berikut:

\section{2}

Uji Validitas Variabel Motivasi Kerja (X1)

\begin{tabular}{|c|c|c|c|}
\hline $\begin{array}{c}\text { Pernyataan } \\
(\mathrm{P})\end{array}$ & $\begin{array}{c}\mathrm{r} \\
\text { hitung }\end{array}$ & $\begin{array}{c}\mathrm{r} \\
\text { tabel }\end{array}$ & Ket \\
\hline P1 & 0,504 & 0,312 & Valid \\
\hline P2 & 0,490 & 0,312 & Valid \\
\hline P3 & 0,563 & 0,312 & Valid \\
\hline P4 & 0,578 & 0,312 & Valid \\
\hline P5 & 0,316 & 0,312 & Valid \\
\hline P6 & 0,331 & 0,312 & Valid \\
\hline P7 & 0,526 & 0,312 & Valid \\
\hline P8 & 0,451 & 0,312 & Valid \\
\hline P9 & 0,677 & 0,312 & Valid \\
\hline P10 & 0,703 & 0,312 & Valid \\
\hline
\end{tabular}

4.3

Uji Validitas Variabel Kompensasi (X2)

\begin{tabular}{|c|c|c|c|}
\hline $\begin{array}{c}\text { Pernyataa } \\
\mathrm{n}(\mathrm{P})\end{array}$ & $\begin{array}{c}\mathrm{r} \\
\text { hitung }\end{array}$ & $\begin{array}{c}\mathrm{r} \\
\text { tabel }\end{array}$ & Ket \\
\hline P1 & 0,401 & 0,312 & Valid \\
\hline P2 & 0,332 & 0,312 & Valid \\
\hline P3 & 0,346 & 0,312 & Valid \\
\hline P4 & 0,657 & 0,312 & Valid \\
\hline P5 & 0,626 & 0,312 & Valid \\
\hline P6 & 0,499 & 0,312 & Valid \\
\hline P7 & 0,736 & 0,312 & Valid \\
\hline P8 & 0,616 & 0,312 & Valid \\
\hline P9 & 0,586 & 0,312 & Valid \\
\hline P10 & 0,622 & 0,312 & Valid \\
\hline
\end{tabular}

\section{4}

Uji Validitas Variabel Kinerja Karyawan (Y)

\begin{tabular}{|c|c|c|c|}
\hline $\begin{array}{c}\text { Pernyataan } \\
(\mathrm{P})\end{array}$ & $\begin{array}{c}\mathrm{r} \\
\text { hitung }\end{array}$ & $\begin{array}{c}\mathrm{r} \\
\text { tabel }\end{array}$ & Ket \\
\hline P1 & 0,431 & 0,312 & Valid \\
\hline P2 & 0,631 & 0,312 & Valid \\
\hline P3 & 0,388 & 0,312 & Valid \\
\hline P4 & 0,769 & 0,312 & Valid \\
\hline P5 & 0,569 & 0,312 & Valid \\
\hline P6 & 0,555 & 0,312 & Valid \\
\hline
\end{tabular}

\begin{tabular}{|c|c|c|c|}
\hline P7 & 0,606 & 0,312 & Valid \\
\hline P8 & 0,350 & 0,312 & Valid \\
\hline P9 & 0,381 & 0,312 & Valid \\
\hline P10 & 0,337 & 0,312 & Valid \\
\hline
\end{tabular}

Terlihat pada tabel bahwa nilai pearson tiap item indikator ketiga variabel 0,000 $(<0,05)$. Artinya seluruh item indikator valid dan dapat diukur.

\subsubsection{Hasil Uji Reabilitas}

Hasil uji ditampilkan pada tabel berikut:

Tabel 4.5 Uji Reliabilitas

\begin{tabular}{|l|l|l|l|}
\hline Variabel & $\begin{array}{l}\text { N of } \\
\text { item } \\
\text { s }\end{array}$ & $\begin{array}{l}\text { Cronbah } \\
\text { 's Alpha }\end{array}$ & $\begin{array}{l}\text { Keputusa } \\
\mathbf{n}\end{array}$ \\
\hline $\begin{array}{l}\text { Motivasi } \\
\text { Kerja }\end{array}$ & 10 & 0,672 & Reliable \\
\hline $\begin{array}{l}\text { Kompensa } \\
\text { si }\end{array}$ & 10 & 0,738 & Reliable \\
\hline $\begin{array}{l}\text { Kinerja } \\
\text { Karyawan }\end{array}$ & 10 & 0.674 & Reliable \\
\hline
\end{tabular}

Terlihat pada tabel dimana ketiga variabel memiliki nilai koefisien $>0,6$ maka terlihat Reliable atau konsisten dan bisa dilanjutkan untuk penelitian selanjutnya.

\subsubsection{Hasil Analisa Regresi Berganda}

Hasil uji ditampilkan pada tabel berikut:

Tabel 4.6 Uji Regresi Berganda

\begin{tabular}{|l|c|c|l|}
\hline \multirow{1}{*}{ Model } & \multicolumn{2}{|c|}{$\begin{array}{l}\text { Unstandardized } \\
\text { Coefficients }\end{array}$} & $\begin{array}{l}\text { Standardi } \\
\text { zed } \\
\text { Coefficie } \\
\text { nts }\end{array}$ \\
\cline { 2 - 4 } & B & $\begin{array}{c}\text { Std } \\
\text { Error }\end{array}$ & Beta \\
\hline 1 & & 6,495 & \\
(Constant) & 19,77 &, 125 &,- 100 \\
MK & 3 &, 114 &, 666 \\
K &,- 100 & & \\
\hline
\end{tabular}

Bentuk persamaan sebagai berikut: $\mathrm{Y}=19,773-0,100 \mathrm{X}_{1}+0,612 \mathrm{X}_{2}$ 
Kesimpulan:

- Terdapat pengaruh negatif variabel motivasi kerja $\left(\mathrm{X}_{1}\right)$ pada kinerja karyawan (Y) sebesar -0,100.

- Terdapat pengaruh positif variabel kompensasi $\left(\mathrm{X}_{2}\right)$ pada kinerja karyawan (Y) sebesar 0,612.

\subsubsection{Hasil Uji Hipotesis}

\section{Hasil Uji t}

Hasil uji ditampilkan pada tabel berikut:

Tabel 4.7 Hasil Uji t

\begin{tabular}{|c|c|c|c|c|}
\hline \multirow[t]{2}{*}{ Model } & \multirow[t]{2}{*}{$\mathrm{t}$} & \multirow[t]{2}{*}{ Sig } & \multicolumn{2}{|c|}{$\begin{array}{l}\text { Collinearity } \\
\text { Statistics }\end{array}$} \\
\hline & & & $\begin{array}{l}\text { Tolera } \\
\text { nce }\end{array}$ & VIF \\
\hline Constant & $\begin{array}{l}5,91 \\
1\end{array}$ & $\begin{array}{l}, 00 \\
0\end{array}$ & & \\
\hline Motivasi & $-\overline{-}$ & $\begin{array}{l}86 \\
6\end{array}$ & ,959 & $\begin{array}{l}1,04 \\
3\end{array}$ \\
\hline $\begin{array}{l}\text { Kompens } \\
\text { asi }\end{array}$ & $\begin{array}{l}5,34 \\
4\end{array}$ & $\begin{array}{l}, 00 \\
0\end{array}$ & ,959 & $\begin{array}{l}1,04 \\
3\end{array}$ \\
\hline
\end{tabular}

Kesimpulan:

- Signifikasi variabel motivasi kerja (MK) $\quad 0,000 \quad(<0,05)$. Terdapat pengaruh signifikan variabel motivasi kerja terhadap kinerja karyawan.

- Signifikasi variabel kompensasi (K) $0,000 \quad(<0,05)$. Terdapat pengaruh signifikan variabel kompensasi terhadap kinerja karyawan.

2. Hasil Uji Goodness of Fit (Uji F dan $\mathbf{R}^{2}$ )

A. Hasil Uji F (Uji Simultan)

Hasil uji ditampilkan pada tabel berikut:

Tabel 4.8 Hasil Uji F

\begin{tabular}{|l|l|l|l|l|l|}
\hline $\begin{array}{l}\text { Mode } \\
1\end{array}$ & $\begin{array}{l}\text { Su } \\
\mathrm{m} \\
\text { of } \\
\text { Squ } \\
\text { ares }\end{array}$ & $\begin{array}{l}\text { d } \\
\text { f }\end{array}$ & $\begin{array}{l}\text { Me } \\
\text { an } \\
\text { Squ } \\
\text { are }\end{array}$ & F & $\begin{array}{l}\text { Si } \\
\mathrm{g}\end{array}$ \\
\hline $\begin{array}{l}\text { Regre } \\
\text { ssion }\end{array}$ & $\begin{array}{l}218, \\
474\end{array}$ & 2 & 109, & $\begin{array}{l}14, \\
237\end{array}$ & $\begin{array}{l}47 \\
7\end{array}$ \\
\hline
\end{tabular}

\begin{tabular}{|l|l|l|l|l|l|}
\hline Resid & 279, & 3 & 7,54 & & \\
ual & 301 & 9 & 9 & & \\
Total & 497, & & & & \\
& 775 & & & & \\
\hline
\end{tabular}

a. Dependent Variable : Kinerja

b. Pedictors: (Constant), Motivasi, Kompensasi

Terlihat pada tabel signifikansi $0,000 \quad(<0,05)$. Terdapat pengaruh signifikan variabel motivasi kerja dan kompensasi terhadap variabel kinerja karyawan secara simultan.

B. Hasil Koefisien Determinasi $\left(\mathrm{R}^{2}\right)$

Hasil uji ditampilkan pada tabel berikut:

Tabel 4.9 Hasil Koefisien

Determinasi

\begin{tabular}{|l|l|l|l|l|}
\hline $\begin{array}{l}\text { Mo } \\
\text { del }\end{array}$ & $\mathrm{R}$ & $\begin{array}{l}\mathrm{R} \\
\text { Squ } \\
\text { are }\end{array}$ & $\begin{array}{l}\text { Adjus } \\
\text { ted R } \\
\text { Squar } \\
\mathrm{e}\end{array}$ & $\begin{array}{l}\text { Std. } \\
\text { Error } \\
\text { of the } \\
\text { Estim } \\
\text { ate }\end{array}$ \\
\hline 1 &, 66 &, 439 &, 409 & 2,747 \\
$2^{\mathrm{a}}$ & & & \\
\hline
\end{tabular}

a. Predictors : (Constant), Motivasi, Kompensasi

Terlihat pada tabel besarnya Adjusted $R$ Square 0,409. Hal ini berarti $40.9 \%$ variabel Kinerja Karyawan (Y) dapat dijelaskan oleh variabel bebas.

\subsection{Pembahasan}

Sesuai dengan data pada analisa regresi berganda dan uji hipotesis, diperoleh informasi sebagai berikut:

1. Berdasarkan hasil pengolahan data diperoleh data sebagai berikut : variabel motivasi kerja memiliki thitung sebesar $-0,170$, sehingga dapat dijelaskan bahwa secara parsial variabel motivasi kerja tidak mempunyai pengaruh yang signifikan terhadap kinerja karyawan.

2. Variabel kompensasi memiliki thitung sebesar 5,344 sehingga dapat dijelaskan bahwa secara parsial 
JRNAL ПММАH

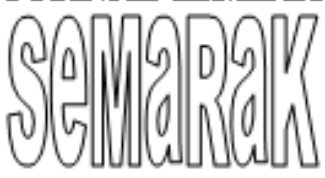

variabel kompensasi mempunyai pengaruh yang signifikan terhadap kinerja karyawan.

\section{PENUTUP}

\subsection{Kesimpulan}

Dari hasil penelitian dan analisis pengaruh motivasi kerja dan kompensasi terhadap kinerja karyawan di PT. Laris Indo Sukses Gemilang Tangerang Selatan maka ditarik kesimpulan sebagai berikut:

1. Persamaan regresi yang diperoleh:

$$
\mathrm{Y}=19,773-0,100 \mathrm{X}_{1}+0,612 \mathrm{X}_{2}
$$

2. Berdasarkan uji statistik secara parsial variabel motivasi kerja tidak mempunyai pengaruh yang signifikan terhadap Kinerja, karena nilai thitung sebesar $-0,170$, sedangkan nilai $t_{\text {tabe }}$ untuk $n=40$ adalah sebesar 1,683 . Jadi $-0,170<1,683$.

3. Berdasarkan uji statistik secara parsial variabel kompensasi mempunyai pengaruh yang signifikan terhadap kinerja, karena nilai $t_{\text {hitung }}$ sebesar 5,344 , sedangkan nilai $t_{\text {tabel }}$ untuk $n=40$ adalah sebesar 1,683. Jadi 5,344 > 1,683 .

4. Terdapat pengaruh secara bersamasama (simultan) antara motivasi kerja dan kompensasi terhadap kinerja karyawan terbukti kebenarannya. Hal ini terlihat dari Uji $\mathrm{F}$ dengan angka signifikansi sebesar $0,000(<0,05)$.

\subsection{Saran}

Sesuai dengan hasil penelitian, saran kepada PT. Laris Indo Sukses Gemilang Tangerang Selatan sebagai berikut:

1. Variabel motivasi kerja menunjukan adanya kelemahan perusahaan dalam menyediakan sarana berorganisasi bagi karyawannya, oleh karena itu disarankan perusahaan menyediakan wadah organisasi bagi karyawan seperti serikat pekerja untuk menampung aspirasi seluruh karyawan.

2. Variabel kompensasi menunjukan adanya kelemahan perusahaan dalam memberikan gaji yang belum sesuai dengan harapan karyawan, oleh karena itu diharapkan perusahaan dapat memberikan gaji dan tunjangan sesuai kinerja karyawan tersebut.

\section{DAFTAR PUSTAKA}

A.A Anwar Prabu Mangkunegara (2012). Manajemen Sumber Daya Manusia. Bandung: PT. Remaja Rosdakarya.

Amirullah. 2016. Pengantar Manajemen. Jakarta: Mitra Wacana Media

Amstrong, Gary \& Philip, Kotler. 2012 Dasar-Dasar Pemasaran. Jilid I, Alih Bahasa Alexander Sindoro dan Benyamin Molan. Jakarta: Penerbit Prenhalindo.

Arikunto, Suharsimi. 2012. Prosedur Penelitian Suatu Pendekatan Praktek. Jakarta: Rineka Cipta

Dessler, Gary. 2012. Manajemen Sumber Daya Manusia. Jakarta: Indeks

Edy Sutrisno. 2016. Manajemen Sumber Daya Manusia. Cetakan ke-8. Jakarta : Prenada Media Group dissertation, Cape Technikon, Cape Town.

Ghozali, Imam. 2017. Aplikasi Analisis Multivariate Dengan SPSS. Cetakan keempat. Badan Penerbit Universitas Diponegoro, Semarang

Griffin. 2012. Customer Loyalty: Menumbuhkan \& mempertahankan Kesetiaan Pelanggan. Dialihbahasakan oleh: Dwi Kartini Yahya. Jakarta Erlangga

Handoko. 2012. Manajemen Personalia dan Sumberdaya Manusia Edisi Kedua. BPFE: Yogyakarta

Hani Handoko Edisi 2 Manajemen Personalia dan Manajemen Sumber daya manusia (2013:53)

Hasibuan, M. 2013. Manajemen Sumber Daya Manusia dan Kunci Keberhasilan. Jakarta: Haji Mas Agung. 
JRNAL ПMПAH

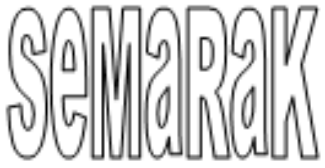

Henry Simamora, 2012. Manajemen Sumber Daya Manusia. Edisi 1. Yogyakarta: STIE YKPN Yogyakarta

Krisnaldy, K., Pasaribu, V. L. D., \& Senen, S. (2019). Pengaruh Budaya Organisasi, Lingkungan Kerja Dan Iklim Organisasi Terhadap Motivasi Pegawai Serta Dampaknya Terhadap Kepuasan Kerja. Jurnal Semarak, 2(2), 164-183.

Krisnaldy, K., Pasaribu, V. L. D., \& Batubara, A. S. (2020). Analisis Pengaruh Kedisiplinan Terhadap Performa Pegawai Kelurahan Rempoa, Kota Tangerang Selatan. Jurnal Mandiri: Ilmu Pengetahuan, Seni, Dan Teknologi, 4(2), 131-138.

Pasaribu, V. L. D., \& Krisnaldy, K. (2018). ANALISIS KEPUASAN JAMA'AH PADA KINERJA DEWAN KEMAKMURAN MASJID ALHIDAYAH PERIODE TAHUN 2017. KREATIF: Jurnal Ilmiah Prodi Manajemen Universitas Pamulang, 6(4), 41-51.

Pasaribu, V. L. D., Krisnaldy, K., \& Warasto, H. N. (2020). Pengaruh Gaya Kepemimpinan, Disiplin Kerja Dan Kompensasi Terhadap Kinerja Pegawai (Studi kasus kelurahan Pisangan Ciputat). Jurnal Disrupsi Bisnis: Jurnal Ilmiah Prodi Manajemen, Fakultas Ekonomi, Universitas Pamulang, 3(1).

Pasaribu, V. L. D., \& Yanuarso, B. P. (2021). PENGARUH STRES KERJA DAN DISIPLIN KERJA TERHADAP KINERJA KARYAWAN PADA PT. MULTRITRAN ABADI SRENGSENG JAKARTA BARAT PERIODE 2018. Jurnal Sekretari Universitas Pamulang, 8(1), 60-72.

Rivai, Veithzal, 2012. Manajemen Sumber Daya Manusia untuk Perusahaan : dari Teori Ke Praktik, Edisi
Pertama, Penerbit PT. Raja Grafindo Persada, Jakarta.

Silalahi, Ulber. 2012. Metode Penelitian Sosial. Bandung: Refika Aditama.

Sinungan, Muchdarsyah. (2012 . Produktivitas Apa dan Bagaimana. Bandung: Bumi Aksara.

Wibowo. 20121). Manajemen Kinerja. Jakarta: raja Grafindo Persada. 